МЕТОДИЧНЕ ЗАБЕЗПЕЧЕННЯ ФОРМУВАННЯ ПІДПРИЄМНИЦЬКОЇ КУЛЬТУРИ МАЙБУТНІХ БАКАЛАВРІВ ФІЗИЧНОЇ КУЛЬТУРИ І СПОРТУ

\title{
METHODICAL SUPPORT OF FORMATION OF ENTREPRENEURIAL CULTURE OF FUTURE BACHELORS OF PHYSICAL CULTURE AND SPORT
}

У статті визначено обов'язкові компоненти методичного забезпечення фрормування підприємницької культури здобувачів освіти зі спеціальності 017 Фізична культура і спорт, а саме: навчально-методичні й технологічні складники. Навчально-методичне забезпечення освітнього процесу, спрямованого на фрормування підприємницької культури, умовно поділено на нормативне (що розробляється профрільним міністерством, закладами вищої освіти), предметне (що розробляється безпосередньо науково-педагогічними працівниками), а також інформаційне, яке формується спільними зусиллями всіх суб'єктів освітнього процесу (науковопедагогічними працівниками, закладами вищої освіти, а також здобувачами освіти). До нормативного забезпечення віднесено державний стандарт, освітньо-професійну програму, навчальні плани. Змістове (предметне) забезпечення дає змогу безпосередньо фрормулювати і реалізовувати зміст освіти, супроводжувати аудиторну, індивідуальну і самостійну роботу. Предметне забезпечення освітнього процесу зосереджено в навчально-методичних комплексах дисциплін. Інорормаційне забезпечення інтегрує паперові та електронні інфрормаційні джерела, що репрезентують зміст освіти. Ключовим компонентом технологічного забезпечення визначено модульне об'єктно-орієнтоване динамічне навчальне середовище закладу вищої освіти на основі Moodle - платорорми, що об'єднує педагогів, адміністраторів і здобувачів освіти в одну інтегровану систему для створення персоналізованого навчального середовища. Середовище корисне для контролю викладачами якості найбільш проблематичної частини навчального процесу - самостійної роботи студентів. Водночас доступ до Moodle здебільшого здійснюється користувачами за допомогою особистих цифррових пристроїв, тому під час формування підприємницької культури запропоновано застосування концепції «мобільного навчання» (m-learning), відмінною рисою якого $\in$ me, що воно відбувається в будь-який час $i$ в будь-якому місці. Охарактеризоване методичне забезпечення дає змогу виконати вимоги нормативних документів і лічензійні умови щодо забезпечення здобувачів освіти всім необхідним для успішної самостійної навчальної праці, а також надати їм потрібні для цього методичні засоби. Основною функцією описаного вище навчально-методичного і технологічного забезпечення процесу формування підприємницької культури визначено забезпечення самостійної роботи студентів.
Ключові слова: підприємницька культура, методичне забезпечення, державний стандарт, освітньо-професійна програма, навчальний план, навчально-методичний комплекс, навчальне середовище Moodle, хмарний сервіс.

The article identifies the mandatory components of methodological support for the formation of entrepreneurial culture of students majoring in 017 Physical Culture and Sports, namely: educational and methodological and technological components. Educational and methodological support of the educational process aimed at forming an entrepreneurial culture is conditionally divided into normative which is developed by the relevant ministry, higher education institutions, subject which is elaborated directly by scientific and pedagogical staff, and informational, which is formed by joint efforts of all subjects of the educational process including research and teaching staff, institutions of higher education, as well as students. The normative support includes the state standard, educational and professional program and curricula. Content support allows you to directly formulate and implement the content of education, to assist in classroom individual and independent work. Subject support of the educational process is concentrated in the educational and methodological complexes of disciplines. Information support integrates paper and electronic information sources representing the content of education. The key component of the technology support is the modular objectoriented dynamic learning environment of the higher education institution based on Moodle -the platform that combines teachers, administrators and students in one integrated system to create a personalized learning environment. The environment is useful for teachers to control the quality of the most problematic part of the educational process which is the independent work of students. At the same time, access to Moodle is mostly provided by users via personal digital devices, so in the formation of entrepreneurial culture proposed the use of the concept of "mobile learning" (m-learning), the distinguishing feature of which is that it occurs at any time and at any time, where the described methodological support allows to fulfill the requirements of normative documents and license conditions for providing students with everything necessary for successful independent educational work, as well as to provide them with the necessary methodological tools.

Key words: entrepreneurial culture methodological support, state standard, educational and professional program, curriculum, educational and methodical complex, Moodle learning environment, cloud service. та спорту

Запорізького національного університету
Постановка проблеми в загальному вигляді. У галузі вищої освіти нашої країни відбуваються скоординовані позитивні трансорормації, пов'язані 3 підвищенням якості освітнього процесу в закладах вищої освіти (3ВО), спрямовані на передання, засвоєння, примноження й використання знань, умінь та інших компетентностей осіб, які навчаються, а також на формування гармонійно розвиненої особистості. Якість освітнього процесу та чесність щодо зацікавлених сторін повинні 
забезпечуватися увагою до якості методичного забезпечення, ретельним аудитом фрорм і методів формування підприємницької культури майбутніх бакалаврів фрізичної культури і спорту, а також розробленням схеми методичного супроводу виконання студентами вимог освітньо-професійної програми.

Аналіз останніх досліджень і публікацій. Попередній аналіз нормативних джерел дозволяє стверджувати, що на сьогодні в нашій країні вимоги до методичного забезпечення освітнього процесу $3 В 0$ є більш-менш усталеними [4; 12; 14; 17-21]. Водночас увагу вчених останнім часом сорокусовано на питаннях систематизації науковометодичного забезпечення в ЗВО [1; 6; 24]; удосконалення методичного забезпечення з урахуванням тенденцій діджиталізації вищої освіти [3; 9; 13]; використання кращого світового досвіду методичного забезпечення освітніх програм [16].

Виділення не вирішених раніше частин загальної проблеми. У науковому дискурсі існує деяка невизначеність щодо використання термінів «навчально-методичне забезпечення», «науковометодичне забезпечення», «інфрормаційне забезпечення», «технологічне забезпечення» тощо. Вважаємо, що необхідно уточнення їх використання у нашому дискурсі.

Спираючись на спроби класифікації методичного забезпечення освітнього процесу 3ВО, зроблені попередниками [24], поділяємо таке забезпечення на навчально-методичне, що інтегрує нормативне, змістове (предметне), а також індрормаційне забезпечення та технологічне забезпечення. Вважаємо також, що навчально-методичне забезпечення принципово відрізняється за своєю природою від технологічного забезпечення: у першому випадку - це документи, а у другому - це технології. Утім вони є взаємозалежними.

Метою статті $€$ визначення обов'язкових компонентів методичного забезпечення фрормування підприємницької культури здобувачів освіти зі спеціальності 017 Фізична культура і спорт.

Виклад основного матеріалу. Для відображення взаємозв'язку між видами забезпечення освітнього процесу вважаємо за доцільне вдатися до побудови карти концептів предметної області «Методичне забезпечення фрормування підприємницької культури» (рис. 1). Як бачимо 3 концепт-карти, навчально-методичне забезпечення освітнього процесу, спрямованого на фрормування підприємницької культури, умовно можна поділити на нормативне (що розробляється профільним міністерством, ЗВО), предметне (що розробляється безпосередньо науково-педагогічними працівниками), а також інформаційне, яке фрормується спільними зусиллями усіх суб'єктів освітнього процесу (науково-педагогічними працівниками, 3ВО, а також здобувачами освіти).
До нормативного забезпечення віднесено державний стандарт, освітньо-профресійну програму, навчальні плани. Відповідальність за створення державного стандарту несе МОН України [14].

Він визначає об'єкт вивчення та діяльності здобувачів освіти; завдання освітнього процесу, сорормульовані у термінах компетентнісного підходу; орієнтовний зміст навчання; методи, методики та технології, що можуть бути використані в освітньому процесі [23].

Усе зазначене створює належну компетентнісну базу для конструювання процесу фрормування підприємницької культури здобувачів освіти зі спеціальності 017 Фізична культура і спорт.

Спираючись на державний стандарт, ЗВО мають право самостійно вирішувати питання складу та змісту навчально-методичного забезпечення освітнього процесу з урахуванням вимог законодавства [21; 24]. Зважаючи на це, у вітчизняній освіті виявляється тенденція до урізноманітнення змісту освітньо-профресійних програм (ОПП) підготовки студентів спеціальності 017 Фізична культура і спорт на тлі стандартизації та уніфрікації структури і методики розроблення навчальних програм. Цей момент відіграє ключову роль у контексті фрормування підприємницької культури, адже ми маємо змогу не тільки визначити пріоритети освітнього процесу, але й творчо конструювати його, забезпечуючи варіативність, диджиталізацію, етапність процесу фрормування цільової профресійної якості.

Освітньо-професійна програма $€$ системою освітніх компонентів на відповідному рівні вищої освіти в межах спеціальності, що визначає вимоги до рівня освіти осіб, які можуть розпочати навчання за цією програмою, перелік навчальних дисциплін і логічну послідовність їх вивчення, кількість кредитів Європейської кредитної трансорерно-накопичувальної системи, необхідних для виконання цієї програми, а також очікувані результати навчання (компетентності), якими повинен оволодіти здобувач відповідного ступеня вищої освіти [18]. Розроблення ОПП щодо фрормулювання цілей і завдань теоретичної та практичної підготовки, визначення іï змісту повинно здійснюватися у тісній співпраці з роботодавцями. При цьому зміст освітньо-профресійної програми повинен повністю відповідати вимогам професійного стандарту.

На підставі ОПП розробляють навчальний план, який визначає: перелік та обсяг навчальних дисциплін у кредитах ЄКТС; послідовність вивчення дисциплін; фрорми проведення навчальних занять та їх обсяг; графрік освітнього процесу; фрорми поточного і підсумкового контролю.

Наступним складником навчально-методичного забезпечення $є$ змістове (предметне) забезпечення, яке дозволяє безпосередньо фрормулювати і реалізовувати зміст освіти, супроводжувати ауди- 


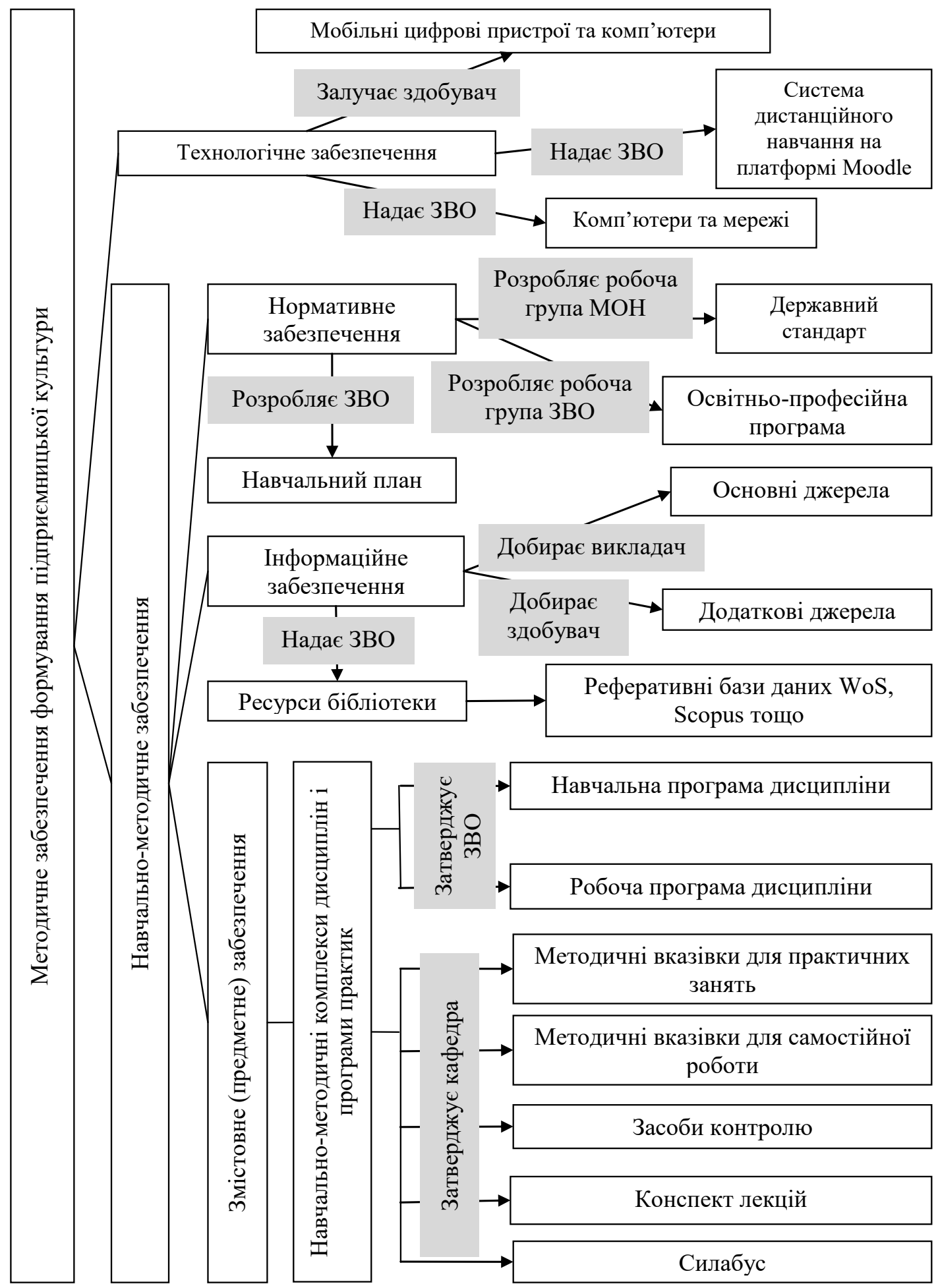

Рис. 1. Концепт-карта предметної області «Методичне забезпечення формування підприємницької культури»

торну, індивідуальну і самостійну роботу. Обов'язок створювати й постійно оновлювати документи, що відносяться до даного виду забезпечення безпосередньо покладається на науково-педагогічних працівників. При цьому вони це можуть робити як індивідуально (план-конспект занять, фондова лекція тощо), так і у групах (наприклад, авторські колективи посібників) [21]. Зазначимо, що форми цього забезпечення, з одного боку, є достатньо стандартизованими (наприклад, фоорми навчальних, робочих програм дисциплін), а 3 іншого розроблення їхнього змісту $є$ процесом творчим, результати цієї роботи репрезентують індивідуальний стиль кожного окремого викладача.

Предметне забезпечення освітнього процесу зосереджено у навчально-методичних комплек- 
сах дисциплін, під якими розуміється сукупність нормативних та навчально-методичних матеріалів на паперовій та/або в електронній фрормах, необхідних і достатніх для ефективного виконання студентами робочої програми навчальної дисципліни, передбаченої навчальним планом підготовки студентів відповідного освітньо-кваліфрікаційного рівня за певним напрямом підготовки (спеціальністю).

Навчально-методичний комплекс (НMK) призначений забезпечити: надання навчальної інформації та її сприйняття, набуття, закріплення й удосконалення знань, умінь і навичок, їх застосування й контролю та основних функцій освітнього процесу - освітньої, виховної та розвиваючої [25]. Зміст НМК має складатися 3 двох компонентів: матеріали щодо планування вивчення дисципліни; матеріали змістового наповнення навчальної дисципліни [6].

Усі компоненти ОПП повинні мати силабуси, що містять основні характеристики курсу та його короткий опис, та представлені у найбільш зручній для здобувача освіти фрормі [6; 16]. Силабус виступає в якості своєрідного «контракту» між науковопедагогічним працівником і здобувачем освіти, який сприяє встановленню й підтримці комунікації між ними. До того ж він дає можливість студентам самостійно структурувати свої зусилля для визначення та досягнення мети вивчення дисципліни, розуміти логіку і методи фрормування освітніх результатів, а також засобів оцінювання навчальних досягнень [5]. Окрема увага повинна приділятися тому, щоб силабуси вибіркових навчальних дисциплін були доступні здобувачам освіти на момент здійснення вибору дисциплін на наступний семестр (навчальний рік).

Відповідно до концепт-карти, поряд із нормативним та предметним забезпеченням, фрормування підприємницької культури студентів спеціальності 017 Фізична культура і спорт включає також інформаційне забезпечення, яке інтегрує паперові та електронні інформаційні джерела, що репрезентують зміст освіти. Інформаційне забезпечення освітнього процесу виступає перш за все як фрункція наукової бібліотеки ЗВО, яка у своєму розпорядженні має фонд видань, читальні зали, а також електронні ресурси. У контексті фрормування підприємницької культури найбільш цінним визначаємо сайт бібліотеки, через електронний каталог якого зареєстрований користувач отримує доступ до:

- каталогу інструктивних видань, навчальнометодичних матеріалів, що зберігаються у паперовій формі у бібліотеці;

- каталогу повнотекстових видань, що зберігаються у паперовому вигляді у бібліотеці (спеціальна і загальна література, довідники, автореферати дисертацій, періодика тощо);
- видань, які зберігаються в електронній фрормі на сервері 3ВО;

- спеціалізованих ресурсів Internet (наукові журнали за профрілем спеціальності 017 Фізична культура і спорт, сайт Національної бібліотеки імені І. Вернадського тощо);

- баз даних WoS та Scopus.

Важливість наступного технологічного складника методичного забезпечення прямо витікає з Закону України «Про вищу освіту», де у ст. 16 3-поміж іншого вказується на необхідність забезпечення 3ВО певними ресурсами для організації освітнього процесу, зокрема самостійної роботи студентів за кожною освітньою програмою [18]. Ключовим компонентом такого забезпечення вважаємо модульне об'єктно-орієнтоване динамічне навчальне середовище 3ВО на основі Moodle однієї з платформ, призначених для об'єднання педагогів, адміністраторів і здобувачів освіти в одну інтегровану систему для створення персоналізованого навчального середовища (learning management system (LMS)) [23].

У контексті формування підприємницької культури найбільш цінним вважаємо те, що Moodle дозволяє розширити «географрію» навчальної діяльності, зокрема, таке середовище дозволяє реалізувати поза межами навчального закладу: вивчення нового матеріалу, поточний контроль знань 3 оцінкою й висновками, колективну навчальну роботу, консультацію 3 викладачем тощо. Окрім цього, інфрормаційне середовище дозволяє студенту не тільки визначити оптимальну траєкторію вивчення матеріалу, але й темп роботи, що відповідає його психофізіологічним особливостям.

Важливим також $є$ і те, що таке середовище корисне для контролю викладачами якості найбільш проблематичної частини навчального процесу - самостійної роботи студентів [2; 10; 11]. Створює та адмініструє середовище Moodle освітній заклад. Проте його контенти розробляють науково-педагогічні працівники.

Впровадження платформи Moodle диктує потребу в розвинутій комп'ютерній мережі, серверах та пристроях, за допомогою яких можливе адміністрування та доступ до цієї платорорми. Однак доступ до середовища Moodle реально здійснюється не тільки і не стільки з використанням ресурсів ЗВО, скільки з використанням користувачами особистих цифрових пристроїв. Тому, перш за все, у процесі фрормування підприємницької культури нашу увагу привернула можливість використання мобільних цифрових пристроїв, за допомогою яких у суб'єктів навчання є миттєвий доступ до навчальних матеріалів і програм, навчальних ресурсів, викання завдань, спілкування між собою та 3 педагогом незалежно від часу й місця знаходження [22, с. 26]. Використання здобувачами 
освіти та викладачами власних комп'ютерів теж мало місце, однак, ми звернули увагу на те, що воно, у порівнянні із використанням мобільних пристроїв, поступово відходить на другий план.

Інакше кажучи, під час фрормування підприємницької культури, ми звернулися до концепції «мобільного навчання» (m-learning), відмінною рисою якого $є$ те, що воно відбувається в будьякий час (специфріка доступу до навчальної інорормації) і в будь-якому місці (територіальна локалізація навчальної взаємодії) [3; 7; 8; 13; 15].

Окрім навчального середовища, комп'ютерів та комп'ютерних мереж до технологічного забезпечення відносимо також й сторонні хмарні сервіси (public cloud services) - програми і платорорми, які розміщено на серверах хмарних провайдерів. Головна особливість таких сервісів у тому, що, створюючи акаунт на них, користувач може отримувати доступ до власної інформації з будь-якого пристрою та у будь-якому місці світу.

Серед таких сервісів, використаних у процесі формування підприємницької культури, ми виділяємо Google Classroom, який за своїм призначенням близький до Moodle, проте дозволяє викладачам організовувати освітній процес незалежно від ресурсів 3ВО (у деяких випадках така можливість $\epsilon$ важливою).

Також у технологічному забезпеченні певне місце посідає сервіс Wix, який дозволяє створювати викладачам персональні сайти. Такі сайти $€$ своєрідними вебпорталами до індивідуального освітнього ресурсу викладача, використовуючи який він отримує змогу створити більш креативний, індивідуалізований та гнучкий освітній продукт.

Висновки. Методичне забезпечення фрормування підприємницької культури майбутніх бакалаврів фрізичної культури і спорту інтегрує у собі навчально-методичне й технологічне забезпечення. Навчально-методичне забезпечення містить: нормативне забезпечення (державний стандарт підготовки здобувачів освіти за спеціальністю 017 Фізична культура і спорт, освітньо-профресійну програму, навчальні плани), змістове (предметне) забезпечення (навчально-методичні комплекси компонентів освітньої програми) та інфрормаційне забезпечення. Технологічне забезпечення потребує створення модульного об'єктно-орієнтованого динамічного навчального середовища Moodle та комп'ютерних мереж, наявності комп'ютерних пристроїв у ЗВО, комп'ютерів та мобільних пристроїв у здобувачів освіти та викладачів, а також використання сторонніх хмарних сервісів.

Охарактеризоване методичне забезпечення дозволяє виконати вимоги нормативних документів та ліцензійні умови щодо забезпечення здобувачів освіти всім необхідним для успішної самостійної навчальної праці, а також надати їм потрібні для цього методичні засоби (навчальну літературу, лабораторне обладнання й устаткування, електронно-обчислювальну техніку тощо). Вважаємо основною фрункцією описаного вище навчально-методичного і технологічного забезпечення процесу формування підприємницької культури супровід саме самостійної роботи студентів. Перспективами подальших розвідок у зазначеному напрямі може бути визначення найбільш доцільних фрорм і методів організації навчання.

\section{БІБЛІОГРАФІЧНИЙ СПИСОК:}

1. Биков В.Ю. Теоретико-методологічні засади моделювання навчального середовища сучасних педагогічних систем. Інфрормаційні технолодії $і$ засоби навчання. Електронне наукове фрахове видання. 2006. Вип. 1. URL: http://www.nbuv.gov.ua/ejournals/ITZN/em1/emg.html.

2. Болюбаш Н.М. Фактори та умови фрормування просресійної компетентності майбутніх економістів засобами інфрормаційного середовища MOODLE. Інформаційні технології і засоби навчання. 2010. № 3 (17). URL: http://www.ime.edu-ua.net/em.html.

3. Бугайчук К.Л. Мобільне навчання: сутніть і моделі впровадження в навчальний процес вищих навчальних закладів МВС України. Інфрормаційні технології і засоби навчання. 2012. № 1 (27). URL: http://www.journal.iitta.gov.ua.

4. Глосарій: затверджено рішенням Національного агентства із забезпечення якості вищої освіти. Протокол від 29 серпня 2019 р. № 9. URL: http:// blogs.kpi.kharkov.ua/v2/quality/wp-content/uploads/ sites/25/2019/09/ Glosarij-NAZYAVO.pdf.

5. Каштанова С.Н., Кудрявцев В.А. Силабус как инструмент регулирования учебной деятельности студентов. Вестник Мининского университета. 2016. № 2. URL: https://cyberleninka.ru/article/n/ sillabus-kak-instrument-regulirovaniya-uchebnoydeyatelnosti-studentov.

6. Ковтун О.В. Навчально-методичний супровід процесу формування професійного мовлення у майбутніх фахівців авіаційної галузі. Матеріали II всеукр. наук. конфр. $з$ міжнар. участю «Сучасні соціальногуманітарні дискурси» (20 жовтня 2012 р.). Дніпропетрвськ: ТОВ «Інновація», 2012. Ч. 1. С. 54-58.

7. Козяр М.М., Кузик А.Д. Використання мобільних телекомунікаційних пристроїв у системі підготовки фрахівців оперативно-рятувальної служби цивільного захисту. URL: http://ubgd.Iviv.ua/wapport/ html/noaooij_1.html.

8. Куклев В.А. Становление системы мобильного обучения в открытом дистанционном образовании: автореф. дис. ... д-ра пед. наук: 13.00.01. Ульяновск, 2010. 46 c

9. Кулініч О. А. Методичний супровід упровадження інноваційних технологій у навчальний процес. URL: http://nmc-pto.zp.ua/wp-content/uploads/2015/04/ Kulinich-O.A._Metodychnyj-suprovid-uprovadzhennyainnovatsijnyh-tehnolohij-u-navchalnyj-protses.pdf.

10. Кустовська І.М. Формування профресійно значущих умінь і навичок майбутніх економістів у вищих навчальних закладах: автореф. дис... канд. пед. наук: 13.00.04 «Теорія і методика професійної освіти». Вінниця, 2011. 21 с. 
11. Кустовський С.М. Дидактичні умови організації самостійної навчально-пізнавальної діяльності майбутніх економістів у вищих навчальних закладах: дис. ... канд. пед. наук: 13.00.04. Вінниця, 2005. 255 c.

12. Ліцензійні умови провадження освітньої діяльності. В редакції постанови Кабінету Міністрів України від 10 травня 2018 р. № 347. URL: https:// zakon.rada.gov.ua/laws/show/1187-2015-п.

13. Любченко В.В., Шинкарюк А.С. Метод построения учебной траектории в условиях мобильного обучения. Вестник НТУ «ХПИ». Тематический выпуск: Информатика и моделирование. 2011. № 17. С. 81-85.

14. Методичні рекомендації щодо розроблення стандартів вищої освіти: Наказ Міністерства освіти і науки України від 01 червня 2017 № 600. URL: https://mon.gov.ua/storage/app/media/vishcha-osvita/ rekomendatsii-1648.pdf.

15. Нестеренко О.А. Навчання іноземних мов 3 використанням мобільних пристроїв. URL: http://ubgd. Iviv.ua/konferenc/kon ikt/Section6/Nesterenko.pdf.

16. Нурманбетова Д.Н., Нефедова Л.В. Методические рекомендации по разработке силлабусов. Издание третье, переработанное и дополненное. Астана, ЕНУ имени Л.Н. Гумилева, 2011. 40 с.

17. Порадник щодо заповнення відомостей самооцінювання освітньої програми (для закладів вищої освіти). URL: https://naqa.gov.ua/wp-content/ uploads/2019/09Порадник-для-3ВО-ост.pdf.

18. Про вищу освіту : Закон України від 01.07.2014 № 1556-VII. URL: https://zakon.rada.gov.ua/laws/ show/1556-18\#Text.

19. Про освіту : Закон України від 05.09.2017 № 2145-VIII. URL: https://zakon.rada.gov.ua/laws/ show/2145-19\#Text.

20. Рекомендації до структури та змісту робочої програми навчальної дисципліни. Додаток 2 до Листа
Міністерства освіти і науки України від 09.07.2018 № 1/9-434. URL: https://mon.gov.ua/ua/npa/list-mon19-434-vid-09072018-roku-shodo-rekomendacij-znavchalno-metodichnogo-zabezpechennya.

21. Рекомендації з навчально-методичного забезпечення навчальних дисциплін у закладах вищої освіти. Додаток 1 до Листа Міністерства освіти і науки України від 09.07.2018 № 1/9-434. URL: https:// mon.gov.ua/ua/npa/list-mon-19-434-vid-09072018roku-shodo-rekomendacij-z-navchalno-metodichnogozabezpechennya.

22. Рєутова В.В. Розвиток інорормаційної культури вчителів основ економіки в системі післядипломної освіти: дис. ... канд. пед. наук: 13.00.04. Запоріжжя: Класич. приват. ун-т, 2013. 226 с.

23. Стандарт вищої освіти України перший (бакалаврський) рівень, галузь знань 01 «Освіта/Педагогіка», спеціальність 017 «Фізична культура і спорт». Затверджено і введено в дію наказом МОН України № 567 від 24.04. 2019 р. 12 c. URL: https://mon.gov. ua/storage/app/media/vishcha-osvita/zatverdzeni\%20 standarty/2019/04/25/017-fizichna-kultura-i-sportbakalavr.pdf.

24. Топчій О.В. Науково-методичне забезпечення освітнього процесу у вищому юридичному навчальному закладі. 2016. GOAL. URL: http://goal-int.org/ naukovo-metodichne-zabezpechennya-osvitnogoprocesu-u-vishhomu-yuridichnomu-navchalnomuzakladi/.

25. Чепуренко Я.О. Навчально-методичний комплекс як вид навчального видання. Актуальні проблеми теорії соціальних комунікацій: Матеріали науково-звітної конореренції викладачів кафедри журналістики Інституту української фрілології та літературної творчості ім. А. Малишка НПУ ім. М.П. Драгоманова: збірник наукових доповідей. Вип. III. Київ : Ореол-сервіс, 2013. С. 7-14. 